\title{
Institutionalization of Democratic Institutions, Challenges, and Prospects Post-1991 Ethiopia: The Electoral Process of Ethiopia
}

\author{
Birhanu Tobe Toyilo \\ Department of Civics and Ethical Studies, Mettu University, Mettu, Ethiopia
}

Email address:

hatabirhanumittu@gmail.com

\section{To cite this article:}

Birhanu Tobe Toyilo. Institutionalization of Democratic Institutions, Challenges, and Prospects Post-1991 Ethiopia: The Electoral Process of Ethiopia. Advances in Sciences and Humanities. Vol. 7, No. 3, 2021, pp. 59-65. doi: 10.11648/j.ash.20210703.13

Received: July 1, 2021; Accepted: July 30, 2021; Published: August 23, 2021

\begin{abstract}
The electoral process is understood as a continuous process often divided into three periods: the pre-election, Election and post-election period. The harmonies run of this course of action can support the democratic system. Currently, it has become an essential component of democratic development too. Due to this, countries in the world have started to look critically about election management for supporting the electoral process, Ethiopia is no exception. Since the adoption of multiparty politics in 1991 the electoral process and its practice become challenge in Ethiopia. So this paper aimed at assessing the challenges and prospects of institutionalizing the electoral process of Ethiopia since 1991. To this end, a descriptive case study design and qualitative approach were employed to gather data from both primary and secondary sources. Primary data were collected using in-depth interviews, key-informants, and FGD methods from purposively selected individuals. Again secondary data such as Books, a chapter in a book, a journal article, other research works, and webpages were used. It also employed the grounded theory analysis method, the data obtained from data collection was followed by creating themes, identification of topics, and sub-topics that are organized and rearranged logically by the investigator to make the analysis more convenient. The finding of the study shows that the Electoral process faces a continuous challenge from both the side of NEBE which exhibited sluggish institutional development with influenced and unprofessional electoral official made trouble on the issue of integrality in the conduct election. Outside of the board insecurity, Electoral conflict, and inactive Media and NGOs, inequitable representation and incompetent parties were the challenges of the electoral process. Conversely, there were practical attempts on the quality of conducting a free and fair election. However, it was not sufficient for institutionalizing the electoral process. The study revealed that the government could play a role as advocator, initiator, and implementer of reform agendas in cooperation with opposition political parties. Medias and NGOs can undertake civic and voter educations, both are 'Watchdogs' and can monitor the election process. Finally, the technical or material support given as a form of Electoral assistance is significant to the electoral process. Accordingly, the prospects were the opening of political space, reforms, and experience of the board, reforms on other mutual democratic institutions, and the flourishing of various independent Media. Further, the confidence of the board can initiate external electoral support and assistance, including Diasporas.
\end{abstract}

Keywords: Electoral Process, Institutionalization, Challenges, Prospects

\section{Introduction}

Democratic institutions are in essence a set of arrangements for organizing political competition, legitimizing rules and implementing rule. The dominant western tradition of analysis holds that these institutions are the building blocks of democracy. In 1980s and early 1990s, many countries in Africa, Latin America and Asia adopted liberal democratic system of governance; with the hope of managing political affairs at best [1].

Since the early 1990s, majority of African countries have undergone momentous transitions from one-party, military or autocratic rule to multiparty democratic systems based on majority rule and popular participation. At the very heart of these democratic transitions has been the holding of periodic, multiparty elections [2] 
Ethiopia also experienced such development as said by Merara G. [10], 'the year 1991 was the turning point in the history of multiparty politics in Ethiopia. After many years of centralized rule, the country has started to legalize multiparty system by attempting to modernize Ethiopian multiethnic society within the ethnic based government system and multiparty democracy.

The other development in the post-1991 Ethiopian politics was the establishment of new political institutions. Accordingly, the immediate democratic institution established by TGE was national electoral commission in 1992. It was established by proclamation No. 11/1992. However, after the completion of its missions, national election board of Ethiopia replaced the national electoral commission in 1992. The NEBE established by proclamation No. 64/1992 with the objective of among other, ensuring the establishment of government elected through free, fair and impartial elections held in accordance with the Constitution [4].

According to DIP midterm report, the NEBE is the institution that is solely responsible for election management in Ethiopia. It has a mandate, among others, to oversee political campaigns, voter education, and party registration; to implement election codes of conduct; to regulate election observation; to recommend on electoral redistricting and polling stations; to count and declare results; and to prepare a comprehensive report of elections; etc. The NEBE expected to discharge all these duties in an impartial and non-partisan manner. Its credibility being important for its work, it needs to have the capacity to do its business effectively, efficiently, and independently [3].

In 1995, the FDRE constitution institutionalized multiparty democracy and since then Ethiopia held five consecutive national elections that tested the journey of democratization process, promoted new democracy friendly laws and orders, which contain detail lists of human rights, introduction of multi-party politics and inauguration of democratic institutions that are amicable development for the democratization process in the country [4]. Above all those key democratic institutions the founding of NEBE is the central and given due attention.

Like that of other democratic institutions, the (NEBE) requires an integrated organizational stand for discharging constitutional accountability on the entire election management issues and electoral process.

'Process' refers to the rules, procedures and activities relating to, among others, the establishment of electoral bodies, the appointment of their members, the registration of voters, the nomination of candidates, balloting, counting of the ballots, the declaration of results, the selection and training of electoral officials, constituency delimitation, voter education and, in some cases, registration of political parties and supervision of party nomination congresses [11].

The performance of any institution determined by internal and external factors and the same is true for NEBE. Controversy over NEBE goes back to 1992. Somehow, many critics believe that NEBE's overall performance was mixed in 2005. Its functionality was perfect until the final day of election 2005, but the significant delay in counting and aggregation had created conflicts. Along with some decisions of the NEBE, this furthered concerns to the opposition's perception that NEBE was not impartial [5].

Despite the fact that each condition is unique, certain pattern have been identified that put countries in danger of electoral violence. Elections are not inherently a source of violence. However, they can intensify political, ethnic, regional, and religious tensions and spill over into violence, especially if they are not conducted with fitting institutional framework. The post 2005 Ethiopian election crisis which seen as a period of instability and violence need to be mentioned in this account.

It is significant to point out here that even the final political transition in South Africa from minority rule under apartheid to majority democratic rule did not involve violence [16], because the democratic institution among the others robustly supported it.

Practically the democratic institutions that are responsible for administering political system with weak organizational ground are mainly susceptible to violence. In such circumstances, special consideration must be paid to the manner in which electoral management body structured and the system in relation to managing matters.

Clearly, elections are crucial and much of the institutional and legal surrounding of elections has been subject to research. Electoral management bodies have been neglected though, specifically in empirical research [7]. In Ethiopia, this issue has received relatively little attention in the literature. The institutionalizing of electoral process seems to have become relatively less important over the last three decades or so, also because of the emergence of party system and electoral system in leading the researches into new and new areas of concerns.

According to Asefa [8] in Ethiopia there is a problem of finding institutional mechanisms for power diffusion and peaceful power sharing and the nonviolent transfer of political power in a democratic manner. Also Yemane Nagish [17], 'The electoral and other institutions on their parts still failed to show any sort of political impartiality. Particularly, NEBE failed to enjoy any confidence not only from the opposition but from the electorates too'. Cited by Yemane; the earlier president of Ethiopia Dr Negasso Gidada argued that "NEBE has not playing its responsibility to encourage and promote any political party as long as it strengthens the peaceful democratic process". Yared Ayele [18], tried to concluded that more problems in the political spare of Ethiopia arises from and related to the Ethiopian electoral system reform. In general, all these studies are reproving different content of reforms in the Ethiopian politics and the very issue of institutionalizing of electoral process were limited and failed to have an advanced prominence in all those studies.

A long all this I found that institutionalizing electoral process assessment of the challenges and future prospect can have paramount importance in strengthening the boards 
function over the democratization process. Hence, all the findings in the political science are dynamic and not definite; the issue requires further large-scale and practical study on the entire electoral process. This study was intended to assess the institutionalization challenges and prospects over the electoral process of Ethiopia since 1991. The study not only helps to be aware of the past institutionalization challenges of electoral process, but also to examine both overall and deepseated multidimensional claims over the issue which constitute a center since 1991 Ethiopia.

Generally, this research is aspired to answer the following questions:

1) What take place in the practice of national electoral board of Ethiopia in conducting free and fair electoral process?

2) What are the challenges of institutionalizing the electoral process in Ethiopia?

3) Were there practical efforts towards improving the quality of conducting a free and fair election?

4) What were the roles of stakeholders including government towards institutionalizing the electoral process?

5) What are the potential prospects of institutionalizing electoral process in Ethiopia?

\section{Materials and Methods}

Profile/Function of the Study Organization (NEBE)

NEBE Was established in 1992 by proclamation No. 64/1992 and accountable to the HPR and it is an independent and autonomous. After its establishment, the board conducted different elections and there are 547 constituency and 45,812 polling station currently the boards is doing activities for the conduct of 2021 Ethiopian general election preparing personnel's and resources enable to carry out credible election. However, the debates concerning 2021 election still are happening and unresolved.

In Ethiopia, NEBE is the chief election management institution responsible for conducting general and local elections, by-elections, and referenda (requested, for example, by nations, nationalities, and peoples to determine identity, boundaries, reassignment to a region or locality, or broader rights of self-determination).

This study employed a 'descriptive case study design, given that from numerous democratic institutions the study focused merely on the electoral process of national electoral board of Ethiopia. In addition, a qualitative approach employed for collecting and analyzing the data needed to address the objectives. The reason for employing a qualitative method on this study relies on the need to understand the in depth interpretations, varies reflections or thoughts of participants for identifying perspectives about the issue. Moreover, it allows in-depth investigation and has a room for exhaustively searching of the past practices with particular focus on the electoral process over the years. Finally, the existing difficulty in determining sample size also enforced the researcher to implement pure qualitative approach.

The study involved twins' source of data (primary and secondary data sources). Since employing both primary and secondary data on a single research increases the validity, reliability and comprehensiveness of the research [12]. Accordingly, the investigator collected primary data through interviews (in-depth and key informant) and FGD (focus group discussion).

Exhaustive assessment of Secondary data was significant in strengthen the research finding, hence done with reviewing of both published and unpublished resources such as: Books, a chapter in a book, a journal article, other research works, directives of different libraries and a webpage's were exploited in doing the research and for finding profound understating about the subject of the study.

The purposive sampling techniques applied in the study those samples that based on the choices of the researcher. Consequently, the investigator of the study deliberately decided the officials of NEBE, oppositional parties, political activists and intellectuals as units sample that are representative of the stakeholder. However, the maximum sample size for convenience and purposive sample was determined based on data saturation point, given that, the investigator was provided an in-depth interview and FGD for officials of NEBE and key informant interview to oppositional parties, political activists and intellectuals under study.

Jointly in-depth-interview and key informant interviews used to collect qualitative data on the issue under study. It was typically in face-to-face encounters by researcher asking the questions orally recording of respondents, and through email (just one political activist) by providing varies detailed question on the concern. Comprehensive checklist that guides the interview process was there during the interview.

Purposive sampling technique employed in selecting participants of an in-depth interview, aligned with study objective and to have better understanding of the challenges of the institutionalization electoral process and it was conducted with two officials of the board who are permanent employees working as senior communication director and senior human resource officer of the board. Owing to their administrative position, they were the central respondents of the study, and they gave a rich and reliable data on the overall performance of the board. The questions addressed were the purpose, practices, and successes of the board. In addition, in the past the major challenges that, the board faced and possible ways of dealing with the problems and the future homework of the board in general were incorporated in the in-depth interviews.

A key informant interview conducted with three oppositional parties' members who are called [Opp. 1, Opp. 2, and Opp. 3] later in the analysis, two political activists who are also called [Act. 1 and Act. 2] in the analysis, and three intellectuals called [Acdy. 1, Acdy. 2 and Acdy. 3] respectively in the analysis. Consequently they were came up with varies prospect over the issue which amplify the opportunity for triangulation of data. Center of attention of 
the key informant interviews include limitation of the board as far as discharging its constitutional responsibility, the role of stakeholders including government over the institutionalizing electoral process. Furthermore, during the key informant interviews sessions, issues related to institutionalization practices, challenge and prospect of the national electoral board were discussed.

The research conducted using qualitative methods and deployed purposive sampling technique to identify the participant of focus group discussion from the administrative staff of Ethiopian Election Board training center. A focus group discussion with officials held at the National electoral board of Ethiopia training center on Date 03/08/11 afternoon. Participants were seven permanent senior administrators working at the board as held responsible of managing logistic and related issues such as darkroom for all printing matters, distribution and provision of material to all electoral districts and civic education divisions.

The investigator brought and asked broader questions to elicit responses and generated discussion among these participants. The study used FGD on aiming to identify the officials' attitudes, feelings, beliefs, experiences and reactions about their institutional capacity, limitation and prospects of the board by putting them all together for discussion on the issue. This allowed the investigator to obtain detailed information about their personal and group feelings, perceptions and opinions about the institution and it was helpful in raising and providing a broader range of information that supported the triangulation data.

In collecting the primary data, interview guides originally prepared in English and translated in to Amharic for convenience in the interview process. The intention of the study was to get a deeper understanding of the practice, success and challenges of institutionalization of electoral process. Participants of the study ware selected purposively from both national and ethnic based oppositional political parties on the basis of prior election involvement record: from political activists on the basis of relative influence over the existing Ethiopian politics: from intellectuals who are linked with the area under discussion like political scientists and related intellectuals interviewed.

Qualitative data that collected through both interview and FGD analyzed by the use of grounded theory analysis. After the collection of the data, the researchers transcribed the recorded data and immersed with raw data by reviewing it. Followed by reading the transcripts and studying the notes, all of the key issues, concepts, and themes identified. Then after, the raw data rearranged according to the appropriate part of the thematic framework to which they relate or they coded accordingly. Subsequently, based on the similarity of the themes the data discussed and analyzed.

\section{Results and Discussions of the Study}

The data collected from both primary and secondary data sources reveal that the past activities of the board viewed from two central institutional approaches such as building strong institution and ensuring the independence and neutrality of the board. However, the data obtained indicates ineffectiveness of the board in these areas of accountability. There were adoption of different regulations and various capacity-building workshops were conducted to make the board resourceful and independent institution. However, in counter argument the board failed to build strong institution to ensure multi-party system. Opp. 1 and Acdy. 1, 2, argued that there is sluggish institutional development of the board. It legitimized the consolidation of single party system. The board involved in the process of institutional building for ensuring genuine electoral process. However, the process resulted in back and forward movement of the boards' capacity since 1992 .

The Oppositions are going on accusing the board for its partiality to the ruling government. Opp. 1 “... the performance of the board lacks quality, professionalism and accountability". In addition, Opp. 2 noted, “...the past electoral environments were discreetly restrictive, repressive since practically slowed the democratic development in Ethiopia". Therefore, the practice of the board to democratic development is inadequate and control by the incumbents and it affects the independence of board, reduces its efficiency and its contribution to democratic development.

The Electoral process as a continuous activity faces continuous challenges. To the participants of FGD, the board encounters more challenges during post-election periods during supervision the board identified various challenges such as: organizational/structural, management, procedural and capacity challenges ${ }^{1}$. Generally, the challenges related with institutional development have involved both internal and external aspect. The Communication director of the board stated that, "the board usually criticized for being biased and loyal to the ruling party. The government is also repeatedly criticized the board. Plus the board widely viewed as controversial from political organizations, activists and intellectual from political science". The incumbent government puts relative pressure along with solving problems of the board it is against the independent function of the board ${ }^{2}$. Institutionally not developed to maintain absolute independence.

The participants of FDG and HRM noted that continuously the board faced difficulty to find out non-partisan, professional and competent officials. Institutional capacity directly comparative to the human resource quality of the organization staffed and again electoral process quality is much reliant on institutional capacity [19]...EMBs along with specialized technical staffs, requires experts for mobilization of tens of thousands of people on a definite series occasion and for moving of a countless supplies and equipment to different locations. It was the challenge of the boards to boost institutional capacity.

Electoral integrity depends upon; organizational structure, functional capacity and administrative ethos [13].

\footnotetext{
${ }^{1}$ Focus group discussion

${ }^{2}$ Interviewee conducted with Human resource manager
} 
Oppositions emphasized that the re-establishment of perception against the board and retain trust from all to ensure that past misdeeds will not happen again. Opp. 1 "The past two general elections were evident to the problem of electoral integrity. There were opposition parties running, but their campaign abilities were incredibly limited by government control. It was the very challenge for electoral integrity and electoral process in Ethiopia ${ }^{3}$.

A large number of political parties is a situation in which there are many parties but no meaningful party competition or dominant single party. Currently 108 political parties registered by NEBE, some are agreed for coalition. The number of parties challenged the electoral process. All the interviewed Oppositions emphasized their suspicions of Ethiopia's transformation into a one party state. By far weak party system will prevail in the country since the law has no restriction on how many parties will run for a power. Weak party system is hazardous to electoral process.

Act. 2 and all the interviewed academicians emphasized about inclusiveness, and fairness of group representation. First past the post system has a limitation of favoring majority and disregard minority. In 2015, nearly four million people have voted for the opposition but failed to secure the majority votes required to win a seat ${ }^{4}$. Gebremeskel [9] viewed first past the post as ill devised to the current needs and realities. For Yared A. [18] is not accurately reflects the preferences of voters, exclude minority groups in the elected body and wastage of a number of votes.

Security was the other challenges in post 2005 election hundreds of students were arrested also locally prominent members of opposition political parties. Opp. 1... the security threat was not limited to arresting opposition but also led to the arrest of many NGOs leaders. Opp. 2, any political activities and opposition fall upon insecurity. Therefore, that it is against democracy. The electoral board failed to give genuine protection to the mentioned victims as neutral and independent institution. The data from interview Acdy. 2, and Opp. 1, 2, confirmed that electoral security is still main problem or unresolved in Ethiopia.

Ethiopia experienced electoral conflict. Opp. 3 electoral conflict must be considered which persist to other election events and become challenges for the process as a result the electoral conflicts given due attention for its immediate and long-term effects on electoral process ${ }^{5}$.

Government has hold arresting several prominent private newspaper editors and publishers in post 2005 election, until recently blocking Diasporas web. Acdy. 3 and Opp. 2, 3, noted that the Medias shaped and reshaped by the framework of government for public manipulation particularly the stateowned media and government-oriented newspapers. It was against the principle of freedom of Media. The adoption of rigid proclamation that targeted the private Media restricted the role of Media in the electoral process of Ethiopia, which

\footnotetext{
${ }^{3}$ Interview with opposition political party member(1)

${ }^{4}$ Interview with communication director

${ }^{5}$ Interview with opposition political party member(3)
}

is unsatisfactory except the 2005 general election.

Oppositions emphasized that countries must not fail to recognize the role of civil society. According to literatures, the role of NGOs in Ethiopia sensibly observed during the 2005 general election. However, the legal restrictions against the role of civil society organizations limited their role. Act. 1 stated that currently NGOs are closed and they lack official approval from the government and involved in activities and developmental issues with high oversight by the government ${ }^{6}$.

There are varies practical attempt towards the quality of election such as adoption of legal frameworks and rewrite the country's repressive electoral, terrorism, and media laws. In addition, HPR removed Political parties from its list of terrorist organizations. The government released hundreds of political prisoners. Acdy. 3 and Act. 2 emphasized the government to execute the promise of implementing electoral changes and election practice to include partial proportional representation. Nevertheless, NEBE conducted election without fulfilling the criteria set by different organization for the conduct of election.

According to Act. 1 and the $\mathrm{CD}$, the board tried to incorporate principles of democratic election though it was not adequate. NEBE conducted trainings on voting, counting, tabulation, and verification for officers and polling station heads including domestic observers, particularly for respecting the rights of marginalized sectors of society on voting. Political parties also received training on candidate registration in attempt to administer free, fair, and credible election. However, the Freedom house reports consider Ethiopia as non-democratic country.

FDRE allowed election observation by inviting international and local observers. Observation is seen as an assertion of free and fair election of one among the other. Then in 2005 election, observers played an important role in the election. Onwards the number of election observer decline over time. In 2015 election, there were no international observers from western countries, though observers were present from the African Union to monitor the election [6].

Government in opening political space, adopting reform agendas, enhancing law, recognizing the independent function of NEBE, and care for NGOs, the Media and other electoral assistance institutions as advocator, initiator, and implementer of reforms agendas but it was limited. Opp. 3 stated that the role of oversight body (legislature, the judiciary) was limited and unsuccessful in discharging their oversight role. FGD apart from the government, electoral process requires the involvement of political parties, civic organization, and media. For the Act. 2, without their involvement, election process might not be open, fair and democratic.

Open Media is a place for public debate and can undertake civic and voter educations and can monitor the election process. For Opp. 1, 2... the state dominated Medias was unfair. In addition, the $\mathrm{CD}$ viewed that ...Media lack high

\footnotetext{
${ }^{6}$ Interview with political activist(1)
} 
quality professional service including government Media. NGOs can facilitate public debate, and generate opportunity for civic and voter education, maintain a peaceful electoral environment moreover they can support logistic service of NEBE. However, all the stakeholders were not played well the expected role respectively.

For HRM...the future prospect viewed from different aspects the experience of the board, the increased participation and recently made changes in the politics. The accommodating approach of the government over previously labeled 'terrorist party. The establishment of strong coalition blocks ${ }^{7}$. The appointment of independent leader describes that the country readiness and aspiration for a free, fair and genuine election. Practical reforms are on other mutual democratic institution and with flourishing of various independent media. International organization showed their affinity for supporting the electoral process ${ }^{8}$.

\section{Conclusion and Recommendations}

The institutionalization of democratic institution is a response to the new demands and advancement over the democratic transition and consolidation of many countries. Election and electoral surroundings caught a central position in the process. The practice of the board both for building strong institution and to ensure its independence was not completed yet and unsuccessful in boosting its institutional capacity. Weak party system and electoral insecurity accompanied with limited access to media/openness and limited role of NGOs was a challenge for Electoral process. However, there were practical attempts on the quality of election.

Government as advocator, initiator, and implementer of reforms agendas can play significant role in institutionalization of electoral process. Additionally, the institutionalization of electoral process is in need of other actors' involvement, because without their involvement the institutionalization process might not be realized. Political parties by widening their base for better representation, civic societies by educating voters and media by dissemination ethically analyzed information and by organizing political debate between political parties, the legislature and the judiciary for their oversight functions. Moreover, international financial and technical assistance is decisive for integrated electoral management.

The study showed that, institutionalizing of electoral process have numerous prospects. Firstly, the practice of government in opening political space; Secondly, reforms and experience of the board; Thirdly, reforms on other mutual democratic institution human right commission and the judiciary; Fourthly, flourishing of various independent medias relatively nowadays vibrant media are found, and consideration of opposition parties and civil society groups in the composition and mode of

\footnotetext{
${ }^{7}$ Interviewee conducted with Human resource manager

${ }^{8}$ Focus group discussion
}

appointment of the electoral bodies in newly adopted electoral law. Further, the confidence of the board can initiate external electoral support and assistance, Diasporas, civil society organization and the Medias in supporting peaceful elections process.

Institutionalization of electoral process requires an integrated approach with operative of different systems and actors. Government should support the establishment and development of political parties, the Media, and NGOs. Moreover, it should initiate, and implement timely reforms on the politics, maintain law and order and made further efforts to increase the independence board. The NEBE needs to have observable strategy for institutionalizing electoral process. Opposition parties should come up with strong governing team and policies agenda. In addition, adopt intraparty rule and regulation for enhancing party members and follower accountability. Medias are expected to monitor the integrity of the electoral process and undertake public education and provide place for public debate. Finally NGOs should create opportunity for civic and voter education and participation. Moreover, they should aspire to promote a peaceful electoral environment.

\section{Acronyms}

Acdy. 1: Academician One

Acdy. 3: Academician Three

Acdy. 2: Academician Two

Act. 1: Political Activist One

Act. 2: Political Activist Two

CD: Communication Director

FGD: Focus group discussion

HRM: Human Resource Manager

NEBE: National electoral board of Ethiopia

NGOs: Non-governmental organizations

Opp. 1: Opposition political party member one

Opp. 2: Opposition political party member two

Opp. 3: Opposition political party member three

\section{Acknowledgements}

Primarily, my appreciation goes to Mettu University for granting me the opportunity of fully sponsored to this study. I am also grateful to Mr. Ermias Admasu (Assist. Professor), for his persistent and expertise advice in the whole process of working out of this research and, $\mathrm{Mr}$. Abiot Desta (M. A), for his constructive, critical and valuable comments through the research work and professional support and guidance that made this work possible. The researcher is also indebted to all respondents that made this study possible in sharing their thoughts and experiences with me, since my research work would not have been possible without their collaboration. Finally, I am indebted to all intellectuals, political party members and activists who take part in this paper. 


\section{References}

[1] Fukuyama, F. (1992). The End of History and the Last Man. New York: Free Press.

[2] UNDP (2016). Elections in the Sub-Saharan Africa: General Trends, Challenges and Opportunities. Ridge Arena. Ghana.

[3] Cassidy, M., \& Hodge, S. (2010). Ethiopia Democratic Institutions (DIP) Program Mid-term Evaluation. (November), $1-141$.

[4] Hailu, S. (2018). Challenges and Prospects of Democratization Process in Ethiopia.

[5] European Union Election Observation Mission, Ethiopia: Legislative Elections 2005: Final Report.

[6] African Union, 2010. African Union Observer Mission to the Legislative Elections in Ethiopia Final Report Issued at the AU Observer Mission Secretariat, Addis Ababa, 26th May 2010

[7] Anne Van Aaken (2009). Independent electoral management bodies and international election observer missions: Any impact on the observed level of democracy? A conceptual framework. University of Hamburg.

[8] Asefa, S. (2001). Perspectives on Institutional Reform and Development in Ethiopia: The Critical Role of Building Enabling Institutions for Economic Growth and Development. International Conference on African Development Archives.

[9] Gebremeskel Hailu (2016). Reforming the Ethiopian electoral system: looking for the best alternative. Oromia Law Journal [Vol 6, No. 1]

[10] Merara G (2003). Competing Ethnic Nationalism and the Quest for Democracy 1960-2000. Nezerland: N. P Shaker Publishing.

[11] IDEA. (2015). Media assistance and elections.

[12] Kothari, C. R., (2004). Research methodology, methods and Techniques, 2nd ed., New Delhi: Vikas Publishing House Pvt. Ltd.

[13] Norris, P. (2015). The electoral integrity project. The quality of government and why Election fail. Harvard University press.

[14] Proclamation No. 532/2007, Electoral Law of Ethiopia Amendment, Federal Negarit Gazetta, $13^{\text {th }}$ Year No. 54, Addis Ababa

[15] Shimellis Hailu (2017). Challenges and Prospects of Democratization Process in Ethiopia

[16] Sisay Asefa (2003). Developing democratic institutions inEthiopia: the challenge of buildingenabling institutions for economicgrowth and development. Published by Michigan State University Press. Vol. 10.

[17] Yemane Nagish (2010). Ethiopia between "election events": the impact of the 2005 and 2010 pre-election politics on competitive elections. Addis Ababa. Ethiopia.

[18] Yared Ayele (2017), The Need and Impact of Reforming the Ethiopian Electoral. Published by Addis Ababa University.

[19] Klein, Keith. (1995). “Approaches to Conducting Elections: Why an Electoral Commission?" Paper prepared at IFES for presentation to the Constitutional Assembly of the Republic of South Africa. 